\title{
Production of Biogas and Bio-fertilizer from Abattoir Waste as Sustainable Management, Eastern Ethiopia, 2019
}

\author{
${ }^{1 *}$ SINA TEMSGEN TOLERA; ${ }^{1}$ FEKADE KETEMA ALEMU \\ ${ }^{* 1}$ Environmental Toxicology, ${ }^{2}$ Public Health in Epidemiology, College of Health and Medical Sciences, Haramaya University, P.O. Box \\ 235, Harar, Eastern Ethiopia \\ *Corresponding Author Email: sinatem3@gmail.com; Tel: +251913023634
}

\begin{abstract}
Our environment facing by serious problems of high volumes of waste, inadequate disposal system particularly in developing countries worldwide. There is also lack of studies on quantification of abattoir waste and lack of workers awareness towards abattoir waste. Therefore, the purpose of the study was to estimate abattoir waste for bioenergy potential as sustainable management. A cross-sectional study was conducted in four selected abattoirs of Eastern Ethiopia from January $1^{\text {st }}, 2018$ to December $30^{\text {th }}, 2018$. The magnitude of abattoir waste composition were computed based on Aneibo mathematical computational from the actual number of slaughtered livestock. The study demonstrated that four selected abattoirs generates $1,606,403 \mathrm{~kg}$ of abattoir waste per year and using Fed batch Aerobic digester about and $85,139 \mathrm{~m}^{3} /$ year of biogas and $111,249 \mathrm{~kg} /$ year of bio-fertilizer can be produced. The biogas or energy from the waste can replace firewood and charcoal and the expensive fossil fuels. Using Banks mathematical computation about $85,139.20 \mathrm{~m} 3 /$ year of biogas estimated, could cover $36097.43 \mathrm{~kg}$ of liquefied gas or $48129.89 \mathrm{~kg}$ of kerosene or $280757.68 \mathrm{~kg}$ of charcoal or $32086.59 \mathrm{~kg}$ of furnace oil or $56151.5 \mathrm{~kg}$ of petrol or $40108.2 \mathrm{~kg}$ of diesel per a year in same functions. The current estimated bio-fertilizer $(111,249 \mathrm{~kg} / \mathrm{year})$ from four abattoir sites can cover about 2,225 hectares per a year with its advantage and efficiency of soil. When in turned into cost, about $\$ 55,645$ per a year of price could estimate from biogas and bio-fertilizer. The study concluded that huge amount of biogas and dry bio-fertilizer yields could produce from abattoir waste through fed batch anaerobic digestion. Therefore, install fed batch anaerobic digestion plant is recommended to ensure environmental safety and public health.
\end{abstract}

DOI: https://dx.doi.org/10.4314/jasem.v23i12.20

Copyright: Copyright (C) 2019 Sina and Fekade. This is an open access article distributed under the Creative Commons Attribution License (CCL), which permits unrestricted use, distribution, and reproduction in any medium, provided the original work is properly cited.

Dates: Received: 30 November 2019; Revised: 20 December 2019; Accepted: 23 December 2019

Keyword: Abattoir waste, Biogas, Bio-fertilizer, Sustainable management

Abattoirs are where animals such as cattle or goat or sheep and others are slaughtered in for consumption as food and it is also known as slaughterhouse. Livestock production in abattoirs is considered a potential food for the world's needy people and during meat production huge amount of abattoir wastes are generating from them (FAO, 2010). In this way, abattoir waste management is a major challenge in urban areas throughout the world. Here, threat of abattoir waste resulted from improper managements of abattoir waste can therefore exert oxygen demand on the receiving environment or breed large population of decomposers (microorganism) some of which may be pathogenic(Gauri et al., 2006). Especially, lowincome countries show rapid urban growth that is putting extraordinary pressure on gigantic amount of abattoir waste in the urban (Ezeoha and Ugwuishiwu, 2011). The production of meat, from farm to fork, includes not just meat for human consumption and useful by-products like leather and skin, but also waste. Abattoir operations produce a characteristic highly organic waste with relatively high levels of suspended solid, liquid and fat (Aneibo et al. 2009). These countries are the worst it given the deficient waste management programs (Fearon et al., 2014). In most of them haven't organized strategy for disposal of solid as well as liquid wastes generated in abattoirs (Akinro et al., 2011). As FAO (2010) reported, these dumped as solid abattoir wastes without any further processing or composting, or they are washed away. The nature and quantity of the waste varies at each stage, but includes the carcasses of dead animals, parts of animals which are treated as inedible, bones, hides and blood. Approximately $50-54 \%$ of each cow, $52 \%$ of each sheep or goat, $60-62 \%$ of each pig, $68-72 \%$ of each chicken and $78 \%$ of each turkey end up as meat consumed by human beings with the remainder becoming waste after processing (Alonge, 2005). Moreover, of abattoir waste, the volume of waste water from abattoirs is $70-75 \%$ of the abattoir water that contributes to a high organic load as well as a considerable amount of suspended material in the waste (Roberts et al, 2011). This causes pollution has potential to pollute air, water and soil leading to health 
hazards (FAO, 2009). Abattoir wastes affect air quality, agriculture, potable water supplies, and aquatic life, which are also pose risks to human and cause methaemoglobinaemia (Adeyemi and Adeyemo, 2007). Yet, huge amount of wastes generating from selected Eastern Ethiopia abattoirs and they simply discharging and releasing their wastes into open environment without any management system or treatment pond. The authors observed that abattoir wastes are not properly treated and managed. Moreover, there was no data available regarding quantification of abattoir waste for sustainable management. Therefore, the purpose of the study was to estimate abattoir-waste generate from selected abattoirs and estimate its potential for bio-energy as sustainable management.

\section{MATERIALS AND METHODS}

Study Settings: The study areas are found in Eastern Ethiopia; the first three study areas are Harar Abattoir; Haramaya University Abattoir Enterprise and Haramaya abattoirs, which are found in Harar; Haramaya University and Haramaya towns; about 503 $\mathrm{km}, 508 \mathrm{~km}$ and $527 \mathrm{~km}$, respectively far from the national capital Addis Ababa. They are characterized by subtropical highland climate, throughout the year, afternoon temperatures are warm to very warm, cool at mornings and rain falls between March and October (https://en.wikipedia.org/wiki/Harar). The second study is Dire Dawa abattoir, which is found in Dire Dawa Admiration and far $453 \mathrm{kmfrom}$ Addis Ababa. It has $9^{\circ} 36^{\prime} \mathrm{N} 41^{\circ} 52^{\prime}$ Elatitude and longitude with Coordinates of $9^{\circ} 36^{\prime} \mathrm{N} 41^{\circ} 52^{\prime} \mathrm{EThe}$ city is characterized by hot semi-arid climate. The region has two rain seasons; that is, a small rain season from March to April, and more rain season from July to August (https://en.wikipedia.org/wiki/Dire_Dawa).

Study Design: A cross sectional study was conducted in selected abattoirs of Eastern Ethiopia, namely, Haramaya, Haramaya University enterprise, Harar and Dire dawa abattoirs

Abattoir Waste Estimation Methods: All number of slaughtered livestock such as cattle, goats and sheep were collected from January 1st, 2018 to December 30, 2018 from each registry municipalities. For abattoir waste generation Aniebo et al (2009) mathematical model was applied. "One cattle could produce $12.6 \mathrm{~kg}$ of blood waste, $8.0 \mathrm{~kg}$ of intestinal content waste, $6.4 \mathrm{kgof}$ waste tissue waste and $11.8 \mathrm{~kg}$ of bone waste (total 38.8). Similarly, One slaughter Goat $/$ sheep/ could generate $0.72 \mathrm{~kg}$ (blood waste), 1.25 $\mathrm{kg}$ (intestinal content waste), $0.8 \mathrm{~kg}$ (tissue waste) and $2.06 \mathrm{~kg}$ (bone waste (total $4.83 \mathrm{~kg}$ ). $\sum(b L w+B n w+I c w+T w) * N$

Where: $\mathrm{BLw}=$ blood waste, $\mathrm{Bnw}=$ bone waste, $\mathrm{Icw}=$ intestinal content waste and $\mathrm{Tw}=$ tissue waste; " $\mathrm{N}$ " is number of slaughtered livestock.

Estimation of Biogas production from Abattoir waste: In this study, biogas production was calculated following the model of Rao et al. (2000), in which it states 1 ton $(1000 \mathrm{~kg})$ of abattoir waste produces $53 \mathrm{~m}^{3}$ biogas that is $1 \mathrm{Kg}$ of abattoir waste can produce 0.053 $\mathrm{m} 3$ of biogas. Hence, the volume of biogas produced (VBP) may be obtained using the following formula (eqn. 2):

$\mathrm{VBP}=\mathrm{AWG} * 0.053 \mathrm{~m}^{3} / \mathrm{kg}$

Estimation of Energy from Biogas: According to Ngumah et al. (2013), the energy potential of biogas generated is based on the calorific value (high heating value) of the methane content and Rohstoffe (2009) stated that the average calorific value of biogas is 21 $23.5 \mathrm{MJ} / \mathrm{m}^{3}$ (approximately $22.0 \mathrm{MJ} / \mathrm{m}^{3}$ ). Commonly, energy is expressed as Kilo Watt hour (KWh) and 3.6 $\mathrm{MJ}$ is equal to $1 \mathrm{KWh}$. If the $22.0 \mathrm{MJ} / \mathrm{m}^{3}$ of biogas is converted to $\mathrm{KWh}, 1 \mathrm{~m}^{3}$ of biogas has an energy potential of $6.1 \mathrm{KWh}$. Energies (electricity and heat) potential of biogas was estimated based on the energy conversion methods formulated by Banks (2009). According to Banks (2009), the efficiency of biogas to be converted to electricity is $35 \%$ and hence, $6.1 \mathrm{KWh}$ $\mathrm{X} 0.35$ equals to $2.1 .4 \mathrm{kWh}$ (i.e. production potential of $1 \mathrm{~m}^{3}$ of biogas is $2.14 \mathrm{KWh}$. Therefore, the Electricity production potential (EPP), (KWh), may be obtained using the following formula:

$\mathrm{EPP}=\mathrm{VBP} * 2.14 \mathrm{kWh}$

Similarly, Banks (2009) indicated that the efficiency of biogas to be converted to heat energy is $50 \%$ and, thus energy potential of $6.1 \mathrm{KWh}$ X $0.5=3.1 \mathrm{kWh}$. The heat production potential (HPP), (KWh), may be estimated as:

$\mathrm{HPP}=\mathrm{VBP} * 3.1 \mathrm{Kwh}$

Estimation of Cost from biogas energy: Amount of energy produced was estimated based on the current Ethiopian Electric Power Corporation /EEPC/ (2018) into cost; i.e the minimum cost (tariff) of $1 \mathrm{KWh}$ of electricity or heat is $0.021 \mathrm{USD}(0.57 \mathrm{ETB})$.

Cost $=($ Eq. $3 * 0.021 \mathrm{USD})+($ Eq. $4 * 0.021 \mathrm{USD})$

Reduction of GHGs using Biogas technology: To know the Greenhouse emission from dumping sites 
calculated based on IPCC, 2000; B-Sustain 2013a; JGCRI, 2018) mathematical computation, which are summarized as follows:

GHGs emission $=[((\mathrm{Q} \times \mathrm{DOC} \times \mathrm{DOCF} \times \mathrm{F} 1 \times 1.336)$ $-\mathrm{R}) \mathrm{x}(1-\mathrm{OX})]$ x 25

where, $\mathrm{Q}=$ Quantity of abattoir waste expressed in tones $/ \mathrm{kg} /$ from waste records; $\mathrm{DOC}=$ Degradable Organic Carbon of abattoir waste proportion ( default value $(\mathrm{DV})=0.12) ; \mathrm{DOCF}=$ Fraction of degradable organic carbon dissimilated for the abattoir waste $(\mathrm{DV}=0.7) ; \mathrm{F} 1=$ Methane fraction generate from dumping gas $(\mathrm{DV}=0.50) ; 1.336=$ Conversion rate of carbon to methane; $\mathrm{R}=$ Recovered methane during the year, measured in $\mathrm{kg}$ or tones (here no recovered methane); $\mathrm{OX}=$ Oxidation factor $(\mathrm{DV}=0.1$ for wellmanaged and ( $D V=0$ for un managed ); and $25=\mathrm{CH} 4$ global warming potential used to convert the quantity of methane emitted to $\mathrm{CO} 2$-e from the quantity of abattoir waste produced

GHG emissions $(\mathrm{tCO} 2 \mathrm{e})=\mathrm{Qj} \times \mathrm{EFj}$

Where: $\mathbf{t}$ is unit for waste ( $\mathrm{kg}$ or tone); $\mathrm{CO} 2 \mathbf{e}$ is carbon dioxide in equivalence; $\mathrm{Qj}$ is the quantity of waste by type $\mathrm{j}$ (here is only abattoir waste); $\mathrm{EFj}$ is the emission factor of waste type $\mathrm{j}$ for biogas $\left(0.02 \mathrm{kgCO}^{-} \mathrm{e}\right)$. Hence, emission of reduction of GHGs using Biogas (R_GHG_B) will be calculated:

$$
\text { R_GHGs_B= } \sum \text { Eqaution 6- } . \sum \text { Eqaution } 7
$$

Equivalence of Biogas with expensive fossil fuels: As Blottnitz (2010) and B-Sustain (2013a) energy estimation, utilization $1 \mathrm{~m} 3$ of biogas equivalent (Eq_B) to coefficient factor of $0.45 \mathrm{~kg}$ Liquefied Petroleum Gas(LPG) or $0.6 \mathrm{~kg}$ kerosene(K) or $3.50 \mathrm{~kg}$ charcoal/fire wood or $0.4 \mathrm{~kg}$ furnace oil $(\mathrm{F})$ or $0.7 \mathrm{~kg}$ petrol (P) or/ and $0.5 \mathrm{~kg} \operatorname{diesel}(\mathrm{D})$ in the same activities. Thus equivalence biogas with other fossil fuels could be calculated as:

Equivalence Biogas $=\sum C F F * N$

Where, CFF: Coefficient factor for above fuels; N: Volume of biogas produced (i.e. Equation 2)

Bio-Fertilizers Yield Potential Estimation Methods: According to Ngumah et al. (2013), the coefficients used in estimating bio-fertilizer yields were based on the fraction of the dry mass (DM) portion of organic waste that is not converted to biogas. Therefore, in this study, bio-fertilizer was estimated based on the coefficient fraction of the Dry Mass (DM) and Volatile Solid (VS) portion of abattoir waste. According to Dublein and Steinhauser (2008), the DM percentage of fresh organic wastes was given as $15 \%$ for abattoir waste, while the Volatile Solids(VS) is the potentially dry mass (DM) of abattoir waste converted into gas (i.e. dry mass minus mineral content), which was calculated by multiplying $85 \%$ with DM of abattoir waste. In this study, the following formulas were used for calculating DM and VS.

$$
\begin{aligned}
& \mathrm{DM}=\mathrm{AWG} * 0.15(15 \%) \\
& \mathrm{VS}=\mathrm{DM} * 0.85(85 \%)
\end{aligned}
$$

Bio-fertilizer production was estimated from abattoir waste based on Dublein and Steinhauser (2008) coefficient fraction model as following equations of the dry mass portion (DM) and therefore, based on this principle, the Bio-Fertilizer Yield (BFY) of the abattoir waste was calculated considering DM and VS. But according to Burke (2000), $60 \%$ of VS is the actual fraction taken to be converted to biogas and the remaining $40 \%$ portion of VS was considered in BFY computation. Hence the potential of BFY was deduced as:

$$
\mathrm{BFY}=(\mathrm{DM}-\mathrm{VS})+(40 \% * \mathrm{VS})
$$

Estimation of Cost from bio-fertilizer Production: Based Ethiopian Agriculture Ministry Report (2017/18) report, 50kg of UREA and DAP fertilizers are equals to 1230 Ethiopian Birr (ETB) and1, $1455 \mathrm{ETB}$, respectively. We assumed that the price of Bio-fertilizer yields (BFY) was reduced by half $(\approx 50 \%$, i.e. $50 \mathrm{~kg}$ of UREA and DAP equals to 600 Ethiopian Currency or 23.70 US dollar from current price of chemical fertilizers. This Reduction was assumed that, the bio-fertilizer and its benefits among our farmers may low acceptance due to limited awareness about it.

Cost of BFY=NBFY $* 23.70$ (USD)

Where NBFY is stands for Production of biofertilizer in kilogram

Dissemination of the study: The findings of the study was disseminate to Haramaya University Research Office, Haramaya, Harar and Dire Dawa abattoirs. In Addition, attempts to be made to publish of the study.

Data Analysis: Data was entered in to SPSS, Version 20 for analysis. Descriptive statistics such as frequency $(\mathrm{F})$, range, mean $(\mathrm{M})$, sum, percentage and standard deviation (SD) for numerical to summarize and describe the data to make them more graspable 
Ethical Consideration: Permission to conduct this "Grant research coded "HUKT-2018-01-03-63" was provided by Haramaya University Research Partnership and Group Directorate. The reviewer of proposal and Ethics Committee of Haramaya University were approved this research project. Then, Haramaya University Health and Medical Sciences was written the formal letter to Haramaya town, Haramaya University Enterprise, Harar town and Dire Dawa Municipality Authority abattoir service for realization of legal research.

\section{RESULT AND DISCUSION}

Slaughtered Livestock: The study was sought to focus on abattoir waste generation from selected Eastern Ethiopia abattoirs namely: Harar Abattoir, Dire Dawa Abattoir, Haramaya Abattoir and Haramaya University Enterprise Abattoirs. About 18/day and 6,339/year, 110/day and 10,170/year, 28/day and $39,281 /$ year, and 12/day and 4,490/year of livestock were slaughtered in Harar Abattoir, Dire Dawa Abattoir, Haramaya and Haramaya University Enterprise (HU-E) abattoirs, respectively. From total 169 and 60,170 of slaughtered livestock, more than 9, $227 \mathrm{~kg} /$ day and $3,315,357 \mathrm{~kg} /$ year of meat could distribute for surrounding community with year of 2018/2019 (Table 1).

Abattoir Waste Composition and Generation: Aneibo (2009) mathematical computation approach was used to estimate abattoir waste composition generated from the abattoirs during meat production due to its complexity and difficulty of abattoir waste. The main principal abattoir waste compositions considered in this study were blood waste, bone waste, intestinal content waste and tissue were considered in this assumption. During production of meat about $224,366 \mathrm{~kg} /$ year, $1,015,59 \mathrm{~kg} /$ year, $192,253 \mathrm{~kg} /$ year and $174,193 \mathrm{~kg} /$ year of abattoir wastes was estimated from Harar abattoir; Dire Dawa city; Haramaya town; and Hu-enterprise abattoirs, respectively (Table 2). From total abattoir waste generated, the percentage of abattoir waste compositions weight is generated from each abattoirs is varied separately. For instance, 30\%, $30 \%, 31 \%$ and $41 \%$ of bone composition and $32 \%$, $32 \%, 31 \%$ and $21 \%$ of blood waste was estimated from Harar, HU-Enterprise, Dire Dawa and Haramaya abattoirs, respectively (Figure 1). However, the percentage of these abattoir waste compositions was varied generated among selected abattoirs (Figure 1). That means the proportion of abattoir waste compositions generated from selected abattoirs were not be same. This is because of slaughtered livestock type (such as cattle, goats and sheep). For instance, when high number of goat and sheep slaughtered in abattoir it was resulted high amount of bone was estimated and followed by blood, intestinal content and tissue waste, respectively. Such type of waste composition estimation was observed in Haramaya and Dire Dawa Abattoirs. But, blood waste composition was highest among abattoir waste compositions in Harar and Haramaya University enterprise where purely cattle were slaughtered; and then followed by bone, intestinal content and tissues waste composition, respectively (Figure 1). The study indicated abattoir waste generation produced the throughout the year was varied among months due to livestock slaughtered were varied as the result of different fasting and meat-eating holidays. This can result high amount of abattoir waste generation could be obtain from abattoirs was resulted from high number of slaughtered livestock. The study revealed that half percent of abattoir waste generated during study period was from Dire Dawa municipality abattoir. While Harar town municipality, Hawassa University enterprise municipality and Haramaya town municipality was accounted the remaining percentage of abattoir waste compositions in decreasing order (Figure 1). The present study indicated that more than sixth thousand kilogram (more than six ton) of abattoir waste was generated per a day; annually more than two million kilogram (more than two thousand ton) of abattoir waste was estimated from four selected Eastern Ethiopia abattoirs (Table $2)$. As contrast, the current abattoir waste estimated $(1,440,755.26 \mathrm{~kg} /$ year $)$ generated from Dire Dawa Municipality abattoir is higher than with finding $(923,995 \mathrm{~kg} /$ year $)$ obtained from Hawassa Town municipality found in south Ethiopia reported by Tolera et al. (2019). Similarly, it higher than the abattoir waste could generate from Elfora Kombolcha abattoir $(1,234,434 \mathrm{~kg} /$ year $)$ found in North Ethiopia, Adama town abattoir $(895,621 \mathrm{~kg} /$ year $)$ found in South-East Ethiopia and Mekele city abattoir ( $8345678 \mathrm{~kg} /$ year) found in Northern Ethiopia, at which raw data (i.e. slaughtered cattle were reported by Yesihak and Edward (2015). Moreover, it is also higher that the data recorded in Minna abattoir, Abuja Nigeria $(873,810 \mathrm{~kg} /$ year) reported by Ahaneku et al (2015); Tamale municipality abattoir, Ghana $(778,910$ $\mathrm{kg} /$ year) reported Frederick et al (2010). However the finding obtained from Harar town municipality abattoir (494,819.04kg/year); Haramaya municipality abattoir $(432,639.80 \mathrm{~kg} /$ year); Haramaya University enterprise abattoir $(424,860.00 \mathrm{~kg} /$ year $)$ was smaller than the finding reported by (Frederick et al., 2010; Yesihak \& Edward, 2015; Ahaneku et al., 2015; Tolera et al., 2019). Moreover, the current abattoir waste generate could contrasts with other organic municipality wastes that are generating from the 
nearby households of in the same situation living in Eastern Ethiopia. Accordingly, the current estimated abattoir waste generated (Table 2) four abattoirs
$(1,606,403 \mathrm{~kg} /$ year $)$ is higher than municipality waste generated $(154,391.18 \mathrm{~kg} /$ year $)$ from 85 households of Aweday (Beneberu, 2011).

Table 1 Slaughtered livestock in selected municipality abattoirs Eastern Ethiopia, January. 2019

\begin{tabular}{|c|c|c|c|c|c|c|c|c|c|c|c|c|c|c|c|}
\hline \multicolumn{16}{|c|}{ Slaughtered livestock(No) } \\
\hline \multirow{2}{*}{$\begin{array}{l}\text { Abattoirs } \\
\text { Period }\end{array}$} & \multicolumn{3}{|c|}{ Harar town Abattoir } & \multicolumn{3}{|c|}{ Dire Dawa Abattoir } & \multicolumn{3}{|c|}{ Haramaya Abattoir } & \multicolumn{3}{|c|}{ *HU-E Abattoir } & \multicolumn{3}{|c|}{ Grand Total } \\
\hline & 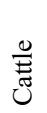 & 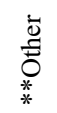 & 吾 & 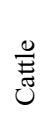 & 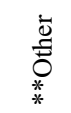 & 吾 & 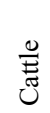 & 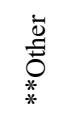 & 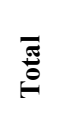 & 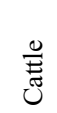 & $\begin{array}{l}\stackrel{\breve{g}}{\tilde{z}} \\
\text { * }\end{array}$ & & 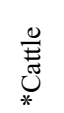 & 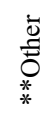 & $\stackrel{\bar{\pi}}{0}$ \\
\hline Daily & $=$ & $\sim$ & 2 & 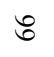 & Ұ & $\stackrel{\varrho}{\varrho}$ & 으 & $\stackrel{\infty}{=}$ & $\stackrel{\sim}{\sim}$ & $\simeq$ & - & $\simeq$ & $\stackrel{\varkappa}{\varrho}$ & t & $\frac{8}{0}$ \\
\hline Week & $\stackrel{\circ}{\circ}$ & $\simeq$ & $\bar{\Xi}$ & ț & 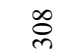 & $\stackrel{5}{5}$ & $\infty$ & $\grave{I}$ & 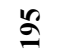 & $\infty$ & & $\infty$ & $\widehat{i}$ & 导 & $\stackrel{n}{=}$ \\
\hline Month & oे & in & $\overline{\widetilde{N}}$ & $\begin{array}{l}\hat{\infty} \\
\stackrel{\sigma}{a}\end{array}$ & 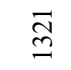 & $\stackrel{\infty}{\stackrel{ల}{~}}$ & $\overline{\grave{\lambda}}$ & 告 & $\infty_{\infty}^{\circ}$ & 유 & - & हे & $\stackrel{0}{=}$ & $\stackrel{\infty}{\sigma}$ & 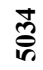 \\
\hline Annually & $\stackrel{\infty}{\stackrel{\infty}{i}}$ & $\overrightarrow{8}$ & త్ల్తి & ڤે & 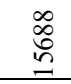 & ळ్̊ & 卓 & 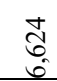 & $\stackrel{?}{\underline{a}}$ & $\begin{array}{l}8 \\
\infty \\
m \\
+\end{array}$ & - & 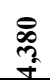 & 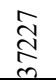 & ๙ิ & $\frac{8}{50}$ \\
\hline
\end{tabular}

Table 2 Annual Estimated of Abattoir Waste Generated From Selected Abattoirs, 2109

\begin{tabular}{lllllll}
\hline & & \multicolumn{5}{c}{ Principal type of abattoir waste compositions } \\
\cline { 3 - 7 } $\begin{array}{l}\text { Name of } \\
\text { abattoirs }\end{array}$ & Livestock & Blood & Bone & Intestinal & Tissue & Total waste \\
content $(\mathrm{kg})$ & Waste(kg) & Waste(Kg) & Waste(kg) & (kg) \\
\hline Harar & 12,339 & 72,325 & 68,609 & 46,421 & 37,011 & 224,366 \\
Dire Dawa & 39,281 & 316,167 & 318,364 & 213,485 & 167,572 & $1,015,591$ \\
Haramaya & 10,170 & 49,414 & 78,241 & 36,624 & 27,974 & 192,253 \\
HU-E & 4,380 & 56,568 & 52,976 & 35,916 & 28,733 & 174,193 \\
Grand total & 66,170 & 494474 & 518190 & 33244 & 261290 & $1,606,403$ \\
\hline
\end{tabular}

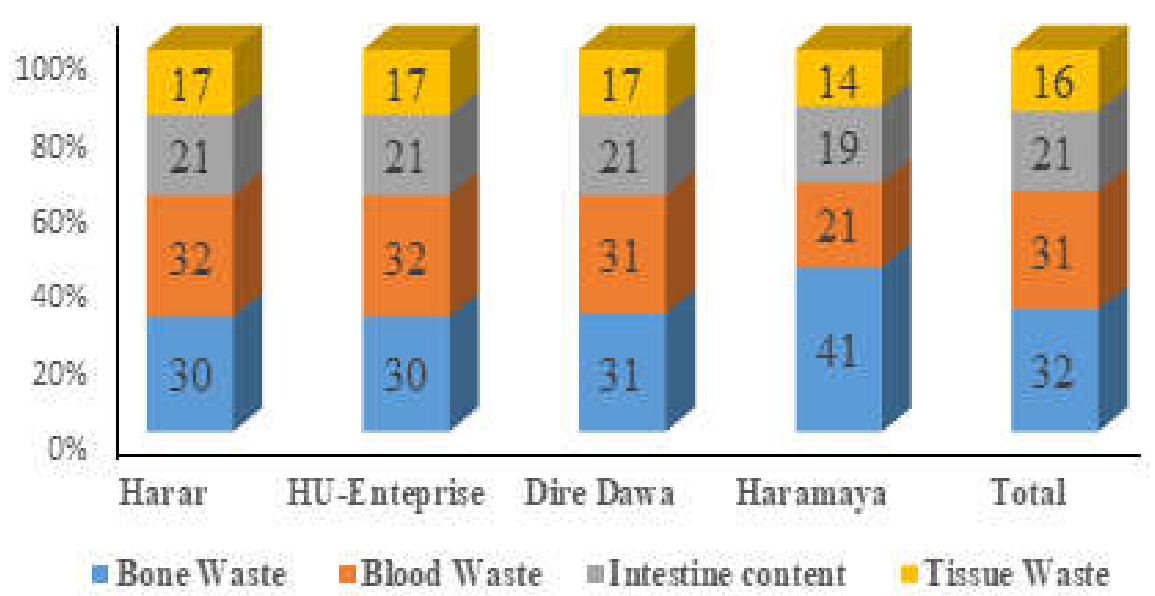

Fig 1 Percentage of Waste Compositions rate of each abattoir from Dec. $1^{\text {st }}$ to 2018-Jan.2019

That means the present abattoir waste generating from four abattoirs is ten time than that of organic waste generated from eighty five households $(10 * 154,391.18 \mathrm{~kg} /$ year$)$. In contrast, However, such huge amount of abattoir waste generating across the country including Ethiopia either in governments' municipalities or owner enterprise abattoirs have no more attention to manage like other municipality waste.

Estimation of Green House gases emission from dumping sites: Field observation showed that huge amount of abattoir wastes were disposed on surrounding environmental without any disposal system (Figure 2). From four abattoirs, improper waste disposal system were observed. About 26942 $\mathrm{kgCO} 2 \mathrm{eq} /$ year, $\quad 118941 \mathrm{kgCO} 2 \mathrm{eq} /$ year, $15354 \mathrm{kgCO} 2 \mathrm{eq} / \mathrm{year}, 20393 \mathrm{kgCO} 2 \mathrm{eq} /$ year of GHGs emission was estimated(Table 2) from disposal $224,366 \mathrm{~kg} /$ year, $1,015,591 \mathrm{~kg} /$ year, $192,253 \mathrm{~kg} /$ year and $174,193 \mathrm{~kg} /$ year of abattoir waste disposed at the sites of Harar Abattoir, Dire Dawa, Haramaya Abattoir and Haramaya University Enterprise abattoir, respectively. Annually, about $887,768 \mathrm{kgCO}_{2}$ eq of GHGs was estimated (Table 2) from $1,606,403 \mathrm{~kg}$ of abattoir waste estimated from the disposed sites of four selected abattoirs found in Eastern Ethiopia. 




Fig 2 Waste disposal site of abattoir waste from selected municipality abattoirs, March, 2019

Table 3 Annual Estimation Greenhouse gases emission from disposal sites of abattoirs, 2019

\begin{tabular}{lllll}
\hline \multirow{2}{*}{ Name of abattoirs } & \multicolumn{3}{c}{ GHGs Emission From Dumping Sites $\left({ }^{*} \mathrm{kgCO}{ }^{-\mathrm{e}}\right)$} \\
\cline { 2 - 5 } & Daily & Weekly & Monthly & Annually \\
\hline Harar & 73.76 & 516.35 & 2212.91 & 26942.22 \\
Dire Dawa & 333.89 & 2337.18 & 10016.14 & $118,941.44$ \\
Haramaya & 63.21 & 316.42 & 1283.08 & $15,353.80$ \\
HU-Ent. & 57.27 & 400.88 & 1718.06 & $20,393.28$ \\
Grand total & 528.13 & 3570.83 & 15230.19 & $181,630.74$ \\
\hline
\end{tabular}

NB: ${ }^{*} \mathrm{kgCO}{ }^{-} e=A$ kilogram of carbon dioxide equivalent, also abbreviated as $\mathbf{k g C O 2 e q}$ is a metric measure used to compare the emissions from various greenhouse gases on the basis of their global-warming potential (GWP).

As many scholars reported improper disposal of wastes like abattoir waste is one of the big problem for climate change over all the world due to greenhouse gases/GHGs/ emission from their disposal sites (Chukwu, 2008). Thus, to estimate greenhouse gases emission from disposal sites, the authors used IPCC (2000) and GWPs coefficient factors. These coefficient factors, it is possible to estimate the amount of GHGs emission from four disposal sites of the selected abattoirs. Table 3 shows that more twenty six thousands of kilogram of carbon dioxide equivalence of greenhouse gases (Table 3) was emitted from almost two hundred twenty four thousands of abattoir waste disposed site of Harar town abattoir per a year(Table 2) ; while more than one hundred eighteen thousand and nine hundreds kilogram of carbon dioxide equivalence of greenhouse gases (Table 3) was estimated from one million and fifteen thousand kilogram of abattoir waste disposed at sites of Dire Dawa administration city municipalities(Table 2) . As combined, more than one hundred eighty one thousand and six hundreds kilogram of carbon dioxide equivalence of greenhouse gases emission (Table 3) was estimated from one million, six hundred thousand and six thousands kilogram of abattoir waste estimated from the disposed sites of four selected abattoirs found in Eastern Ethiopia (Table 2). Hence, such amount of gases contribute to climate change and could enhance greenhouse effect, contribute on the sea-level rise and changes in rainfall patterns with implications for floods and droughts; and changes in the incidence of climatic as Anthony et al (2009) reported. Hereby, these amount of greenhouse gasses emission from the disposal sites of selected municipal abattoirs are one of the significant sources of air pollution at surrounding cities fully and at national level particular.

Potential of Abattoir Waste: Biogas Production, Heat and Electricity and its cost: The table shows about $11892 \mathrm{~m}^{3} /$ year, $53826 \mathrm{~m}^{3} /$ year, $10189 \mathrm{~m}^{3} /$ year and $9263.87 \mathrm{~m}^{3} /$ year of biogas production was estimated from Harar; Dire Dawa; Haramaya; and HU-E abattoirs, respectively (Table 4). Using energy conversion coefficient equations, about 104336.99 $\mathrm{kWh} /$ year, $282049.65 \mathrm{kWh} /$ year, $282049.65 \mathrm{kWh} /$ year and $48,542.68 \mathrm{kWh} /$ year of electricity and heat energy was estimated from Harar town municipality, Dire Dawa administrative municipality city administration, Haramaya town municipality and Haramaya university enterprise abattoirs, respectively (Table 4). When converted biogas into cost, about \$1254.3(35823ETB), \$5624.2(160627ETB), \$1072.2(30623ETB) and \$971.1(27734 ETB) cost was estimated annually from Harar Abattoir; Dire Dawa Abattoir; Haramaya Abattoir; and HU-E abattoir, respectively (Table 4 ). The first product of 
Feed batch Aerobic digester is that it produce biogas, which is environmental friendly product. The current finding revealed that more than two hundreds cubic meters of biogas production was estimated (Table 4) from four selected abattoirs and which could use for cooking, lighting, and heating. From this daily biogas production more than one thousand kilo watt per hour about of energy was estimated and when in turned into cost, more than twenty five dollar or more than six hundred in Ethiopian currency (Birr) price was estimated from these selected abattoirs (Table 4). Our country, Ethiopia has trying to install big project for anaerobic breakdown of organic matter (e.g., animal or human waste, food waste or plant material) ultimately alternative energy in which from to biomass. The country has been started the biogas implementation in the first Growth Transformation Program (GTP-I) and in the phase two (GTP-II) of strategic plan. This strategic plan has multitude of advantages to society and for forming sustainable environment, the wider dissemination of the technology (NBP, 2007). While, GTP-II: Alternative energy strategic to achieve national biogas programs development goals of the second Growth and Transformation Plan (GTP-II) of the country should be a considerable focus on exploiting and initiating abattoir waste as raw materials that generated from other different abattoir operations found in the parts the country (GTP II, 2016-2019/20). Therefore, our finding was inline and encourage this strategic plan in order to any organizations or institutions found in the country could apply bioenergy from organic waste like abattoir waste as sustainable rather than disposing elsewhere.

Possible Reduction of Greenhouses gases Using IPCC (2000), B-Sustain (2013a) and JGCRI (2018) mathematical computation model was applied. In case of Harar abattoir, from $26,942 \mathrm{kgCO}_{2}{ }^{-} \mathrm{e} / \mathrm{year}$ of Greenhouses gases/GHGs/ estimated from disposal sites, could reduce $22,437 \mathrm{kgCO}_{2}$-e/year of GHGs emission using $\mathrm{AD}$ and only $4,486 \mathrm{kgCO}_{2}{ }^{-} \mathrm{e} /$ year of GHGs was estimated from fed batch anaerobic digester (Table 5).

Table 4 Annual Estimation of Energy from estimated biogas of selected abattoirs; Jan, 2019

\begin{tabular}{|c|c|c|c|c|c|c|}
\hline \multirow[b]{2}{*}{$\begin{array}{l}\text { Name of } \\
\text { abattoirs }\end{array}$} & \multirow[b]{2}{*}{$\begin{array}{l}\text { Estimated } \\
\text { waste }(\mathrm{Kg})\end{array}$} & \multirow[b]{2}{*}{$\begin{array}{l}\text { Estimated } \\
\text { Biogas }\left({ }^{*} \mathrm{~m}^{3}\right)\end{array}$} & \multicolumn{4}{|c|}{ Estimated energy from produced biogas and Its cost } \\
\hline & & & $\begin{array}{l}\text { Heat } \\
(* * \mathrm{kWh})\end{array}$ & $\begin{array}{l}\text { Electricity } \\
(\mathrm{kWh})\end{array}$ & $\begin{array}{l}\text { Total } \\
\text { energy(kWh) }\end{array}$ & $\begin{array}{l}\text { Estimated } \\
\text { Cost }(* \$)\end{array}$ \\
\hline Harar & 224,366 & $11,891.61$ & $25,448.1$ & 78888.94 & 104336.99 & 1254.3 \\
\hline Dire Dawa & $1,015,591$ & $53,826.27$ & $115,188.2$ & 166861.4 & 282049.65 & 5624.2 \\
\hline Haramaya & 192,253 & $10,189.25$ & $21,805.00$ & $31,586.7$ & $53,391.67$ & 1072.2 \\
\hline HU-Ent. & 174,193 & $9,263.87$ & $19,824.68$ & $28,718.0$ & $48,542.68$ & 971.1 \\
\hline Grand total & $1,606,403$ & $85,139.20$ & $182,197.9$ & $263,931.5$ & $446,129.41$ & 8901.6 \\
\hline
\end{tabular}

Table 5 Estimation of potential reduction of GHGs emission using anaerobic digester per a year

\begin{tabular}{|c|c|c|c|c|}
\hline \multicolumn{5}{|c|}{ Annual Reduction of GHGs(kgCO2-e) using Anaerobic Digester } \\
\hline $\begin{array}{l}\text { Name of } \\
\text { abattoirs }\end{array}$ & $\begin{array}{l}\text { Estimated } \\
\text { waste }(\mathrm{kg})\end{array}$ & $\begin{array}{l}\text { GHGs Estimated } \\
\text { from dumping }\end{array}$ & $\begin{array}{l}\text { Estimated of } \\
\text { GHGs from AD }\end{array}$ & $\begin{array}{l}\text { Potential of } \mathrm{AD} \\
\text { reduction }\end{array}$ \\
\hline Harar & 224,366 & 26942.22 & 4,486 & 22,437 \\
\hline Dire Dawa & $1,015,591$ & $118,941.44$ & 20,312 & 101,558 \\
\hline Haramaya & 192,253 & $15,353.80$ & 3,843 & 19,225 \\
\hline HU-Ent. & 174,193 & $20,393.28$ & 3,482 & 17,418 \\
\hline Grand total & $1,606,403$ & $181,630.74$ & 32,127 & 160,640 \\
\hline
\end{tabular}

Table 6 Equivalence of estimated biogas with other fossil fuels from selected abattoirs, 2019

\begin{tabular}{lllllllc}
\hline & \multicolumn{6}{c}{ Annual substitution of expensive fuels by utilization of biogas } \\
\cline { 3 - 7 } $\begin{array}{l}\text { Name of } \\
\text { abattoirs }\end{array}$ & $\begin{array}{c}\text { Estimated } \\
\text { Biogas }\left(\mathrm{m}^{3}\right)\end{array}$ & $\begin{array}{l}\text { Liquefied } \\
\text { Gas }(\mathrm{kg})\end{array}$ & $\begin{array}{l}\text { Kerosene } \\
(\mathrm{kg})\end{array}$ & $\begin{array}{l}\text { Charcoal } \\
(\mathrm{kg})\end{array}$ & $\begin{array}{l}\text { Furnace oil } \\
(\mathrm{kg})\end{array}$ & $\begin{array}{c}\text { Petrol }(\mathrm{kg}) \\
\text { Diesel } \\
(\mathrm{kg})\end{array}$ \\
\hline Harar & $11,891.61$ & 5354.77 & 7139.69 & 41648.18 & 4759.79 & 8329.64 & 5949.74 \\
Dire Dawa & $53,826.27$ & 23640.1 & 31520.16 & 183867.6 & 21013.44 & 36773.5 & 26266.8 \\
Haramaya & $10,189.25$ & 3050.42 & 4067.22 & 23725.45 & 2711.48 & 4745.09 & 3389.35 \\
HU-Ent. & $9,263.87$ & 4052.12 & 5402.82 & 31516.45 & 3601.88 & 6303.29 & 4502.35 \\
Grand total & $85,139.20$ & 36097.43 & 48129.89 & 280757.68 & 32086.59 & 56151.5 & 40108.2 \\
\hline \multicolumn{6}{c}{$*$ Indicated unit for biogas is cubic meter; while ** indicated unit for all fossil fuels is kilogram }
\end{tabular}

As showed in table5, the second benefit of AD through biogas is that it can lesser impact of waste from surrounding climatic change (i.e. lesser emission of greenhouse gases into environment), which is currently the issue of world population and government politics. Thus do this, implementation of
$\mathrm{AD}$ is significant. For example, Table 3 shows that more than one hundred eighty one thousand and six hundreds kilogram of carbon dioxide equivalence of greenhouse gases emission $\left(181,630.74 \mathrm{kgCO}_{2}\right.$ eq $)$ (Table 3), which could avoid about one hundred sixty kilogram of carbon dioxide equivalence of greenhouse 
gases $(160,640 \mathrm{kgCO} 2 \mathrm{eq})$ using fed batch anaerobic digester and almost only thirty (Table 5) two thousand kilogram of carbon dioxide equivalence of greenhouse gases $(32,127 \mathrm{kgCO} 2 \mathrm{eq})$ emitted by fed batch anaerobic digester when it implement based on this baseline. Biogas could substitute other fuel fossil: The following table shows that from $85,139.20 \mathrm{~m}^{3} /$ year of biogas estimated, could cover $36097.43 \mathrm{~kg}$ of Liquefied Gas or $48129.89 \mathrm{~kg}$ of Kerosene or $280757.68 \mathrm{~kg}$ of Charcoal or $32086.59 \mathrm{~kg}$ of Furnace oil or $56151.5 \mathrm{~kg}$ of Petrol or $40108.2 \mathrm{~kg}$ of Diesel per a year in same functions (Table 6). As illustrated above table, substitution of biogas instead of other expensive fossil fuels is third vital benefits of biogas. The second benefits of biogas is to substitute the other expensive fossil fuels such as liquefied petroleum gas , kerosene, charcoal, furnace oil, petrol and diesel fuel with the equivalence functions and because biogas is a "cleaner" than these fuels(Charles,2009). For example, almost eighty five thousand of estimated biogas could cover an average per capita consumption more than two hundreds eighty thousand kilogram of charcoal (Table 5). Essentially charcoal and wood fire is common in immediate household those are living in surrounding. So that implement this biogas project for each municipality abattoir could help more than 200 head of households for their daily activities such as cooking, heating and boiling water. Therefore, biogas has the potential to substitute the most expensive finite fossil fuels and charcoal with their drawback with the community. The fourth significant of AD by means of biogas is that it is a supplementary for economy prosperity, social and for country development. In this study, the current finding shows that more than eight thousands of United States dollar (\$8901.6) was estimated from biogas estimated from four selected abattoirs per a year. Scholars confirmed biogas improving economic of the country or abattoir itself through the means of creating markets for surrounding community by leading to lesser the cost (Chukwu et al., 2011).

Bio-Fertilizer Production and with its Cost: Table 7 shows $\quad 45.20 \mathrm{~kg} /$ day and $16,502.11 \mathrm{~kg} /$ year; $204.51 \mathrm{~kg} /$ day and $72,851.63 \mathrm{~kg} /$ year; $38.71 \mathrm{~kg} /$ year and $9,404.20 \mathrm{~kg} /$ year; and $35.08 \mathrm{~kg} / \mathrm{day}$ and $12,490.88 \mathrm{~kg} /$ year of bio-fertilizer was estimated from Harar, Dire Dawa, Haramaya and Haramaya University enterprise abattoirs, respectively(Table 7) . When in turned in to cost, about $19.0(542 \mathrm{ETB}) /$ day and $\$ 6933.7(198,025 \quad$ ETB $) /$ year; $\$ 85.9(2,454 \mathrm{ETB}) /$ day and $\$ 30609.9(874,220$ ETB)/year; \$16.3(465ETB)/day and \$3951.3(112,850 ETB)/year; and $\$ 14.7(421 \mathrm{ETB}) /$ day and \$5248.3(149,891 ETB) of bio-fertilizer was estimated from Harar town abattoir, Dire Dawa administration of abattoir, Haramaya abattoir and Haramaya University enterprise abattoir, respectively (Table 7).

Table 7 Estimation of bio-fertilizer production from abattoir waste of selected abattoirs, 2019

\begin{tabular}{|c|c|c|c|c|c|}
\hline \multirow[b]{2}{*}{$\begin{array}{l}\text { Name of } \\
\text { abattoirs }\end{array}$} & \multirow[b]{2}{*}{$\begin{array}{l}\text { Estimated } \\
\text { Abattoir waste }\end{array}$} & \multicolumn{4}{|c|}{ Estimated Residual for Bio fertilizer and Its Cost Benefits } \\
\hline & & $\begin{array}{l}\text { Dry } \\
\text { Mass/DM/ }\end{array}$ & $\begin{array}{l}\text { Volatile } \\
\text { Solid/VS/ }\end{array}$ & $\begin{array}{l}\text { Bio } \\
\text { fertilizer }(\mathrm{Kg})\end{array}$ & $\begin{array}{l}\text { Estimated Cost } \\
\text { (US dollar) }\end{array}$ \\
\hline Harar & 224,366 & $33,677.77$ & $28,626.10$ & $16,502.11$ & 6933.7 \\
\hline Dire Dawa & $1,015,591$ & $148,676.80$ & $126,375.28$ & $72,851.63$ & 30610 \\
\hline Haramaya & 192,253 & $19,192.25$ & $16,313.41$ & $9,404.20$ & 3951.3 \\
\hline HU-Ent. & 174,193 & $25,491.60$ & $21,667.86$ & $12,490.88$ & 5248.3 \\
\hline Grand total & $1,606,403$ & $227,038.42$ & $192,982.65$ & $111,248.83$ & $46,743.2$ \\
\hline
\end{tabular}

Production of bio-fertilizer, the residual part of abattoir waste is considered the second product of anaerobic digester. The current study shows that about more than one hundreds tones of bio-fertilizer was estimated per a year from four selected abattoir (Table 7). As land coverage, from annual the current estimated of bio-fertilizer, almost two thousands, two hundred and twenty five hectares can cover per year that increased from $15 \%$ to $25 \%$ of total crop yield with advantage and efficiency of soil which was described under website and deal "Agronomies" (Renuka, 2013. Now day, such benefits are important considerations both by government or users. Essentially, bio-fertilizer reduces water and soil pollution, loss of micro-organisms and beneficial insects; overall reduction in soil fertility is some of the ill effects of chemical fertilizers. So that this study give a clue of bio-fertilizers significance which hold promising future in reducing soil quality problems with optimum crop yield for users and farmers as well ( Renuka, 2013). When in turned into price, more than forty six thousands United States dollars $(\$ 46,743.2)$ was estimated from four selected abattoirs found in Eastern Ethiopia (Table 6). The estimation was based on current chemical fertilizer price by considering market feasibility, was considered how bio-fertilizer is perceived in terms of value offered for money spent by customers. In such circumstances, the researchers have decided the price of bio fertilizers along with the risk and responses was weighed. In fact, the current price of chemical fertilizers or inorganic fertilizer used at national level was less halved $(<50 \%)$ to estimate the cost of the current bio-fertilizer. That means such amount of price from inorganic fertilizer was reduced 
by half and the present estimated bio-fertilizer cost, which could be covered two times of hectares as compare to inorganic chemical coverage. In other hands, this income generation is also supplementary of internal revenue for the abattoirs themselves. Therefore, using anaerobic digestion for abattoir waste can provide subsequent generations a more healthy economy, a fairer, a more inclusive society and a cleaner environment (Chukwu et al., 2011). So that present finding encourage 2nd GTP targeted, that recommended as "Every governments' organization should increase their internal resource mobilization of income benefits not less than five percent of their governmental allocation (i.e. $>5 \%$ of normal budget allocation from government) (NPC, $2^{\text {nd }}$ GTP, 2015/2016-2019/20). Moreover, AD is a potential to reduce pollutions, greenhouse gases emissions as compared to other waste treatment. In addition, it has a benefits to mitigate global climate changes and optimize and keep soil health.

Limitation of study: The research didn't deal with number of livestock slaughtered around homes or outside the selected abattoirs including slaughtered camels in these abattoirs. In addition, the magnitude of abattoir waste was estimated based on assumptions that was adopted from other African scholar context, which might be leads either lower or higher abattoir waste estimation record in these study areas due to size of cattle, sheep and goats.

Conclusion: The present study shows that large quantity of abattoir waste was generated as compared to other waste generated, which was directly disposed into the surrounding environment without any disposal system. The study also indicated that huge amount of biogas and bio fertilizer yield obtained through anaerobic digestion indicated that abattoir waste have a potential benefits to ensure environmental safety and public health as means of sustainable management. Thus, the municipality should design abattoir waste treatment technology as sustainable management to safeguard the environment and ensure public health for the as long term plan, while proper abattoir waste disposal will forward as short term.

Acknowledgement: Mostly, we acknowledge Haramaya University in general and Research "Theme I: Productivity and Environmental Sustainability for Food Security and Poverty Alleviation and Research Group and Partnership Directorate of Haramaya University for settled financial support which was coded as HUKT-2018-01-03-63. In addition, we thank Harar town Municipality, Haramaya Town Municipality, Haramaya University Enterprise abattoir and all abattoir service who were supporting and facilitating the activities carried out at their abattoirs.

\section{REFERENCE}

Adeyemi, I. G; Adeyemo, O. K. (2007). Waste management practices at the Bodija abattoir, Nigeria', International Journal of Environmental Studies, 64:1, $71-82$.

Ahaneku, IE; Njemanze, CF. (2015). Flow Analysis of Abattoir Solid Waste Management System in Minna, Nigeria; Res. J. Dairy Sci., 41(2): 165172.

Akinro, A.O; Ologunagba, I. B; Yahaya, O. (2011). Environmental implications of unhygienic operation of a city slaughterhouse in Akure, Western Nigeria. J. Engineering and Applied Sciences; 4(9): 60-63.

Alonge, D.O. (2005). Meat and Milk Hygiene; Ibadan, Nigeria: Farmcoe Press; 64(1):71-82 .

Aniebo, AO; Wekhe SN; Okoli IC. (2009). Abattoir Blood Waste Generation in River State and its Environmental Implications in the Niger Delta. Toxicol. J. Environ. Chem.; 91:619-625.

Beneberu, S. (2011). Generation, composition and characteristics of urban solid waste in a major khat producing and marketing area in Eastern Ethiopia; IJEP; 1(5):.9-16; DOI 10.5963/IJEP0105002

B-sustain. (2013a). Environmental and Social Benefits of Biogas Technology. Retrieved from: http://www.bsustain.in/faqs.html (accessed in March 2015).

Charles Banks. (2009).Optimization of anaerobic digestion to provide energy output via conversion_ retrieved from www.forestry.gov.uk/pdf/.../rrps_AD250309_opt imising anaerobic digestion.pdf

Chima, C. Ngumah; Jude N. Ogbulie; Justina C. Orji; Ekpewerechi S. A. (2103). Biogas potential of organic waste in Nigeria .Journal of Urban and Environmental Engineering; v.7:110-116.

Chukwu, O; Adeoye PA; Chidiebere I (2011).Abattoir wastes generation, management and the environment: Minna, Nigeria; 1, (6):100-109 available on http://www.innspub.net 
Deublien, D; Steinhauser, A. (2008). Biogas from Waste and Renewable Resources, Wiley-VCH; 27-83.

Ezeoha, S.L.; Ugwuishiwu, B.O. (2011). Status of slaughterhouse wastes research in Nigeria. Nigerian Journal of Technology, 30(2):143-148.

Fearon, J; Mensah, S.B; Boateng, V. (2014). Abattoir operations, waste generation and management in the Tamale metropolis of slaughterhouse. Journal of Public Health and Epidemiology; 6(1), pp. 1419

FAO/Food and Agricultural Organization (2010). Abattoir development, Options and designs for hygienic basic and medium-sized: Corporate Document Repository. Retrieved August 16, 2011.

Frederick, A; Ayum, TG; Gifty, AA; Samuel, A. (2010). Microbial Quality of Chevon and Mutton Sold in Tamale Metropolis of Northern Ghana. J. Appl. Sci. Environ. Manage; 14 (4): 53-55.

Gauri, SM; Kashaigili J; Kimwaga, R (2006). Insanitary and pose threats to health and technology in developing countries; 97(9):11191135

IPCC/Intergovernmental Panel on Climate Change (2000). National Greenhouse Gas Inventories and uncertainty management. http:/www.ipccnggip.iges.or.jp/public/gp/gpgaum.htm

JGCRI/Joint Global Change Research Institute (2018). GCAM v4.4 Documentation: Global Change Assessment Model (GCAM): Available online: http://jgcri.github.io/gcam-doc/ (accessed 2018).

NBP/National Biogas Program (2007). First Ethiopian strategic plan (2010-2015 years); retrieved from http://www.biogas in Ethiopia
NPC/National Planning Commission (2016) .Federal Democratic Republic of Ethiopia Growth and Transformation Plan II (GTP II) (2015/162019/20)

Ngumah, CC; Ogbulie, JN; Orji, JC; Amadi, ES (2013). Biogas Potential of Organic Waste Nigeria, J. Urban Environ. Engineer. 7(1):110116

Rao, M. S; Singh. S. P; Singh A. K; Sodha M. S. (2000). Bioenergy conversion studies of the organic fraction of MSW. J Applied Energy; 66: $75-87$.

Rohstoffe, FN. (2009). Biogas basis daten Detsch land- Comprehensive overview of the biogas station in Germany. Retrieved https://www,fnrserver.de/ftp/pdf/literatur/pdf (Accessed 2018).

Renuka

Kholkute (2013).Biofertilizers_Opportunities_and_Challen ges_.pdf-.india (accessed 2018)

Roberts, H. (2011). Waste handling practices at red meat abattoirs in South Africa; 27: 1-25

Salman, Z (2008) .Waste-to-energy consultant, wasteto-energy conversion from retrieved from www.altenergymag.com/content.php?No:08.08.0 1 .

Tolera Sina .T; Sota, Solomon .S; Derebie Ermias; Mekonnen Tesfaye .H (2019). Physico-chemical Qualities of Abattoir Wastewater in Hawassa City, Southern Ethiopia. EAJHBS. : 3(1): 13-20.

Yesihak, Y. Mummed; Edward C. Webb (2015). Operation Facilities and management practice $\mathrm{V}$ 10(7):623-630 